\title{
NATIONAL AND CONSTITUTIONAL IDENTITY IN THE CASE-LAW OF CONSTITUTIONAL COURTS OF THE VISEGRAD GROUP
}

\section{NÁRODNÁ A ÚSTAVNÁ IDENTITA V JUDIKATÚRE ÚSTAVNÝCH SÚDOV ŠTÁTOV VYŠEHRADSKEJ SKUPINY}

\author{
Valéria Miháliková \\ Univerzita Pavla Jozefa Šafárika v Košiciach, Právnická fakulta \\ https://doi.org/10.33542/SIC2020-1-04
}

\begin{abstract}
After the inclusion of the EU's obligation to respect national identities of its Member States into the primary law of the European Union, the notion of national identity has become an object of the interest of constitutional courts of EU Member States. They have, at the same time, started to use the notion of constitutional identity with regard to the European integration in their case-law. The object of this article is to analyse the case-law of the constitutional courts of the Visegrad group regarding the notions of national identity and constitutional identity and to analyse the means of using these concepts in their case-law, in particular with regard to the use of the concept of national identity within the meaning of the Article 4 (2) of the Treaty on European Union in the case-law of the Court of Justice of the European Union.
\end{abstract}

\begin{abstract}
ABSTRAKT
Po tom, čo bola v primárnom práve Európskej únie ustanovená povinnost' Únie rešpektovat' národné identity jej členských štátov, sa stal pojem národná identita čoraz častejším objektom pozornosti ústavných súdov členských štátov Únie. Súčasne sa vjudikatúre týchto súdov začal $v$ súvislosti s európskou integráciou použivat pojem ústavná identita, mnohokrát spájaný práve s národnou identitou. Ciel’om tohto článku je približit' judikatúru ústavných súdov štátov Vyšehradskej skupiny zaoberajúcu sa pojmami národná identita a ústavná identita a zhodnotit' spôsob, akým sú tieto koncepty v ich judikatúre využivané, a to predovšetkým sohl'adom na využitie konceptu národnej identity vzmysle článku 4 ods. 2 Zmluvy o Európskej únii v judikatúre Súdneho dvora Európskej únie.
\end{abstract}

\section{INTRODUCTION}

European Union is without any doubt an extraordinary project. However, the features which make it extraordinary and also fascinating have many times become its stumbling block. EU Member States, having voluntarily conferred the exercise of their competences on the European Union while aiming to fulfil the objectives of the Union provided for in its Founding Treaties, have oftentimes been a perfect example of cooperation in Europe. However, their EU membership brings with it also obstacles arising from the very keystone of this membership - limiting their competences. Gradual extension of the membership base as well as the reforms of the Treaties have been accompanied by the endeavour to resolve the ongoing issue - the relationship between the European Union and its Member States and their respective legal orders. 
One of the manifestations of this endeavour was the inclusion of the EU's obligation to respect national identities of its Member States into the primary law of the European Union, the roots of which may be found in the times of the Maastricht Treaty ${ }^{1}$ preparation. Specific attention has been paid to this obligation during the preparatory work on the so called Constitutional Treaty and later on the Lisbon Treaty from 2009. The result of the treaty-makers' endeavour is therefore the Article 4(2) of the Treaty on the European Union (hereinafter referred to as „TEU“) according to which ,[t] $[$ he Union shall respect the equality of Member States before the Treaties as well as their national identities, inherent in their fundamental structures, political and constitutional, inclusive of regional and local self-government. It shall respect their essential State functions, including ensuring the territorial integrity of the State, maintaining law and order and safeguarding national security. In particular, national security remains the sole responsibility of each Member State. “2

However, although the reference to the national identity in the EU primary law occurred already in 1993, it was its changed version within the Lisbon Treaty, which has begun to attract attention of EU Member States. And because of more frequent references to the national identity in the submissions of national courts of EU Member States, the Court of Justice of the European Union (hereinafter referred to as „CJEU“) could - although in a limited way - clarify the possibilities of the Article 4(2) TEU's application in practice. Even though the number of the CJEU's decisions regarding the national identity has increased over time, national identity in the EU law is still a notion which is approached differently within the literature. To this situation contributes without doubt also a fact that certain - especially constitutional - courts of EU Member States approach the notion of national identity differently and in sharp contrast with the approach of the Court of Justice of the European Union.

The aim of this paper is to describe the way and circumstances in which the national and constitutional identity is approached by constitutional courts of the Visegrad group and compare their approaches with that of the Court of Justice of the European Union. Based on this comparison, it will be possible to conclude whether the national and constitutional identity as comprehended within the case-law of these constitutional courts corresponds to the concept of national identity within the Article 4(2) TEU in a way in which the CJEU interprets it.

\section{NATIONAL IDENTITY AND CONSTITUTIONAL IDENTITY AND PRACTICAL ISSUES REGARDING THE APPLICATION OF THE ARTICLE 4(2) TEU}

One of the matters contributing to ambiguities regarding the concept of national identity within the EU law is its replacing by the concept of constitutional identity. Although the CJEU in its judgments does not explicitly contest the link of the national and constitutional identity, ${ }^{3}$ it cannot be maintained that it uses these notions interchangeably. It is furthermore questionable whether the very notion of constitutional identity is approached in the same way by the CJEU and constitutional courts of EU Member States.

Within the scientific literature, it is possible to find the notions such as national constitutional identity ${ }^{4}$ as well as the cases when the authors use the notion of constitutional identity

Article $\mathrm{F}(1)$ of the Maastricht Treaty stated: „The Union shall respect the national identities of its Member States, whose systems of government are founded on the principles of democracy.“

Treaty on the European Union, OJ C 202, 7.6.2016, p. 13-388.

3 See, in this regard, for example the judgment of the Court of Justice of 22 December 2010, Sayn-Wittgenstein, C-208/08, EU:C:2010:806. Austrian government pointed out national provisions which are according to it a part of the Austrian constitutional identity. Court of Justice stated that the above-mentioned provisions which may be considered to be a part of the Austrian national identity may be taken into consideration while balancing a legitimate interest of Austria and the right to free movement provided for by the EU law.

4 VON BOGDANDY, A. and SCHILL, S. Overcoming Absolute Primacy: Respect for National Identity under the Lisbon Treaty. In Common Market Law Review. ISSN 0165-0750, 2011, vol. 48, no. 5, p. 1417 - 1453. 
and national identity without any regard to the situations within which they are used. ${ }^{5}$ Furthermore, in the judgment of the Constitutional Court of Hungary, there is a notion of constitutional self-identity used - without any further clarification - in connection with the notion of national identity within the Article 4(2) TEU. ${ }^{6}$

According to Cloots, these notions cannot be used interchangeably. She claims that the obligation to respect national identities of the Member States, as enshrined in Article 4(2) TEU, rests on different normative assumptions than the claim, made by certain constitutional courts, that European law must comply with constitutional identity for it to be applicable in the domestic legal order. Whereas the Union's obligation to pay heed to national identity is grounded in a liberal concern for the respectful treatment of the members of a multinational political community, the constitutional courts' preoccupation with constitutional identity rests on a particular conception of sovereignty. Furthermore, according to Cloots, the Treaty makers had good reasons for writing into the EU Treaty a requirement of respect for the Member States' national identities rather than the States' sovereignty or their constitutional identity. ${ }^{7}$

On the contrary, Bogdandy and Schill mention the obligation to respect the national constitutional identity of EU Member States, by pointing out particularly the changed wording of the previous Article $6 \mathrm{TEU}^{8}$ to today's Article 4(2) TEU. According to them, the latter makes it possible to overcome the idea of absolute primacy of EU law and to permit to domestic constitutional courts to invoke, under certain limited circumstances, constitutional limits to the primacy of EU law. ${ }^{9}$

Rosenfeld points out in this regard that it is necessary to differentiate modern constitutional identity from national identity, however, two communities - national and constitutional - are different, although they may overlap and their base may be exactly the same or at least closely linked. Constitutional identity is therefore according to him constructed vis-à-vis national identity, it is, however, consistent with it and has to be continuously in a dynamic tension with national as well as other identities. ${ }^{10}$

The above-mentioned conceptual ambiguities regarding the concept of national identity enshrined in the Article 4(2) TEU are closely linked with its application in practice. National identity used interchangeably as a constitutional identity - as an unamendable core of a Member State's constitution - would result in applying this concept as an exception to the absolute primacy of the EU law over national law of EU Member States. Such understanding of national identity would be contrary to the EU law which - according to the established case-law of the CJEU - has primacy even over constitutional law of an EU Member State. ${ }^{11}$ However, approaching the obligation to respect the national identity as a somehow protective element during EU law-making or as a possibility to justify not fulfilling obligations stemming from EU law for a certain Member State would have foreseeable and less undesirable effects and, what is more, fully consistent with the EU law.

As already mentioned, it is possible to find different opinions in the literature as regards the application of the concept of national identity. According to Bogdandy and Schill, the

5 BLAGOJEVIĆ, A. Procedures Regarding National Identity Clause in the National Constitutional Court's and the CJEU's Case-law. In EU and Comparative Law Issues and Challenges. ISSN 2459-9425, 2017, no. 1, p. 210 - 237.

6 Decision of the Hungarian Constitutional Court of 30 November 2016, 22/2016 (XII. 5.) AB.

7 CLOOTS, E. National Identity, Constitutional Identity and Sovereignty in the EU. In Netherlands Journal of Legal Philosophy, 2016, vol. 45, no. 2, p. $83-84$.

8 Article 6(3) TEU in the wording of the Amsterdam Treaty stated: "The Union shall respect the national identities of its Member States."

9 VON BOGDANDY, A. and SCHILL, S. Overcoming Absolute Primacy: Respect for National Identity under the Lisbon Treaty, op cit., p. 1420.

10 ROSENFELD, M. Constitutional Identity. In ROSENFELD, M. and SAJÓ, A. The Oxford Handbook of Comparative Constitutional Law. Oxford: Oxford University Press, 2012, p. 758.

11 Decision of the Court of Justice of 17 December 1970, Internationale Handelsgesellschaft, 11-70, EU:C:1970:114. 
Article 4(2) TEU may be used as a possibility to overcome the absolute primacy of EU law over national law, because it allows national constitutional courts to invoke, under certain limited circumstances, constitutional limits to the primacy of the law of the European Union. ${ }^{12}$ On the contrary, Guastaferro maintains that the Article 4(2) TEU should be applied within ordinary functioning of the Union and its Member States, thus not only in exceptional cases. ${ }^{13}$

\section{II.NATIONAL AND CONSTITUTIONAL IDENTITY IN THE CASE-LAW OF CON- STIUTIONAL COURTS OF THE VISEGRAD GROUP}

\subsection{Poland}

Polish Constitutional Court mentions in its case-law mostly constitutional identity of Poland, which is, however, part of more widely constructed national identity alongside traditions and culture. In the case-law of Polish Constitutional Court, constitutional identity is clearly linked with the sovereignty of Poland which - together with its independence - means confirmation of the primacy of Polish nation to determine its own fate. The normative manifestation of that principle is inter alia Article 90 of Polish constitution, in the light of which the sovereignty of Poland is expressed in the inalienable competences of the organs of the state, constituting the constitutional identity of the state.

According to the Polish Constitutional Court, the competences under the prohibition of conferral manifest about a constitutional identity and thus they reflect the values the Constitution is based on. Constitutional identity is therefore ,[...] a concept which determines the scope of "excluding - from the competence to confer competences - the matters which constitute [...] "the heart of the matter», i.e. are fundamental to the basis of the political system of a given state" [...], the conferral of which would not be possible pursuant to Article 90 of the Constitution. "14 The competences under the prohibition of conferral are, among others, decisions specifying the fundamental principles of the constitution and decisions concerning the rights of the individual which determine the identity of the state, including, in particular, the requirement of protection of human dignity and constitutional rights, the principle of statehood, the principle of democratic governance, the principle of a state ruled by law, the principle of social justice, the principle of subsidiarity, as well as the requirement of ensuring better implementation of constitutional values and the prohibition to confer the power to amend the Constitution and the competence to determine competences. The guarantee of preserving the constitutional identity of the Republic of Poland has been Article 90 of the Constitution and the limits of conferral of competences specified therein. ${ }^{15}$

The concept of national identity enshrined in the Article 4(2) TEU is, according to the Polish Constitutional Court, an equivalent of the concept of constitutional identity. The latter is closely related to national identity which includes also traditions and culture. In this regard, Trybunat Konstytucyjny pointed out to the Preamble of the Treaty on European Union, that expresses one of the objectives of the European Union, which is to satisfy the desire to deepen the solidarity between their peoples while respecting their history, their culture and their traditions. Polish Constitutional Court then noted that the idea of confirming one's national identi-

\footnotetext{
12 VON BOGDANDY, A. and SCHILL, S. Overcoming Absolute Primacy: Respect for National Identity under the Lisbon Treaty, op cit., p. 3. Similarly, BESSELINK, L.F.M.: National and Constitutional Identity before and after Lisbon. In Utrecht Law Review, ISSN 1871-515X, 2010, vol. 6, no. 3, p. 36 - 49.

13 GUASTAFERRO, B.: Beyond the Exceptionalism of Constitutional Conflicts: The Ordinary Functions of the Identity Clause. Jean Monnet Working Paper 01/12.

14 Decision of the Polish Constitutional Court of 24 November 2010, K 32/09, p. 2.1

15 Ibid.
} 
ty in solidarity with other nations, and not against them, constitutes the main axiological basis of the European Union, in the light of the Treaty of Lisbon. ${ }^{16}$

As regards the conferral of competences, its limit is determined also axiologically in that sense that the Republic of Poland and an organisation or an institution, onto which the competences have been conferred, must embody common system of universal values, such as the system of democratic governance, observance of human rights. ${ }^{17}$ Trybunat Konstytucyjny also added that the values expressed in the constitution and the Treaty of Lisbon determine the axiological identity of Poland and the European Union. At that time only the draft of economic, social and political systems contained in the Treaty, which stipulates the respect for dignity and freedom of the individual, as well as respect for the national identity of the Member States, is fully consistent with the basic values of the Polish Constitution, confirmed in its Preamble, which includes the indication of historical, traditional and cultural context that determines national identity, which is respected in the EU within the meaning of Article 4(2) of the Treaty on European Union. ${ }^{18}$

As stated by Śledzińska-Simon a Ziołkowski, the concept of constitutional identity established by the Polish Tribunal entails substantive limitations on the legislative power of granting consent for the ratification of international treaties conferring competences to an international organization or institution. It also contains a competence norm addressed to the constitutional adjudicator to ensure that the limits of conferral are not overstepped in this process. ${ }^{19}$

\subsection{Hungary}

In relation to the Constitutional Court of Hungary, identity - national as well as constitutional - is mentioned within the literature mostly in connection with the decision 22/2016 (XII. 5.) $\mathrm{AB}^{20}$ regarding the interpretation of the Article $\mathrm{E}(2)$ of the Hungarian Constitution. ${ }^{21}$ According to the Hungarian Constitutional Court, Article E(2) imposes limitations on the transferred and jointly exercised competences. On the one hand, the joint exercising of a competence shall not violate Hungary's sovereignty and on the other hand, it shall not lead to the violation of constitutional identity. ${ }^{22}$

Similarly, as other constitutional courts, Hungarian Constitutional Court maintains that the constitutional self-identity of Hungary is not a list of static and closed values and that it interprets it on a case-by-case basis. Nevertheless, it mentions some constitutional values as an example of what may constitute a constitutional identity - freedoms, the division of powers, republic as the form of government, respect of autonomies under public law, the freedom of religion, exercising lawful authority, parliamentarism, the equality of rights, acknowledging judicial power as well as the protection of the nationalities living in Hungary. ${ }^{23}$ The protection of constitutional self-identity may be raised in the cases having an influence on the living conditions of the individuals, in particular their privacy protected by fundamental rights, on

\footnotetext{
Ibid., p. 2.1.

Ibid., p. 2.2.

Ibid., p. 2.2 .

19 ŚLEDZIŃSKA-SIMON, A. and ZIÓŁKOWSKI, M.: Constitutional Identity of Poland: Is the Emperor Putting on the Old Clothes of Sovereignty? [online] Available at: https://ssrn.com/abstract=2997407.

20 Decision of the Hungarian Constitutional Court of 30 November 2016, 22/2016, (XII. 5.) AB.

21 Article E(2) of the Hungarian constitution states: "With a view to participating in the European Union as a Member State and on the basis of an international treaty, Hungary may, to the extent necessary to exercise the rights and fulfil the obligations deriving from the Founding Treaties, exercise some of its competences arising from the Fundamental Law jointly with other Member States, through the institutions of the European Union. Exercise of competences under this paragraph shall comply with the fundamental rights and freedoms provided for in the Fundamental Law and shall not limit the inalienable right of Hungary to determine its territorial unity, population, form of government and state structure."

22 Ibid., p. 53 and 54.

23 Ibid., p. 64 and 65.
} 
their personal and social security, and on their decision-making responsibility, and when Hungary's linguistic, historical and cultural traditions are affected. ${ }^{24}$

Hungarian Constitutional Court also emphasizes that the constitutional self-identity of Hungary is a fundamental value not created by the Fundamental Law - it is merely acknowledged by the Constitution of Hungary. Consequently, constitutional identity cannot be waived by way of an international treaty and Hungary can only be deprived of its constitutional identity through the final termination of its sovereignty, its independent statehood. Although Hungarian Constitutional Court differentiates between sovereignty and constitutional identity, it points out that these have several common points, thus their control should be performed with due regard to each other. ${ }^{25}$

In connection with the above-mentioned judgment, Kochenov and Bard state that the definition of constitutional identity provided for by the Hungarian Constitutional Court is so vague that it can be considered as an attempt of granting a carte blanche type of derogation to the executive and the legislative from Hungary's obligations under EU law. ${ }^{26}$

While attempting to understand the notion of national as well as constitutional identity from the Hungarian Constitutional Court's point of view, it is almost impossible to overlook the context and circumstances in which the above-mentioned decision was adopted. ${ }^{27}$ Halmai speaks in this regard of the abuse of constitutional identity and points out, inter alia, to the fact that the wording ,the achievements of our historical constitution" in the preamble of Hungarian constitution are utterly ambiguous, since no legal-scientific consensus exists in Hungary as to its precise nature. He also adds that the thousand years of the Hungarian historical constitution - with the exception of some brief moments - the dominant approach was an authoritarian one. Moreover, he straightforwardly links the decision 22/2016 to the unsuccessful attempt of the Hungarian government to change the constitution of Hungary in 2016 with the aim to avoid obligations stemming from the EU law regarding the so called refugee quotas.

As stated by Halmai, when the Hungarian Constitutional Court protects Hungary's constitutional identity using the pretext of protecting the rights of asylum seekers against collective expulsion, but aiming at not taking part in the joint European solution to the refugee crisis, it does so in a way that is inconsistent with the requirement of sincere cooperation under Article 4(3) TEU. It promotes national constitutional identity without accepting the constitutional discipline demanded by the European legal order. Such abuse of constitutional identity is therefore according to him nothing but national constitutional parochialism. ${ }^{28}$

It should be added that the attempts of Hungarian government resulted in the change of the Hungarian constitution in 2018. In its changed wording, the protection of the constitutional identity and Christian culture of Hungary shall be an obligation of every organ of the State. ${ }^{29}$

\subsection{Czech Republic}

Although the Czech Constitutional Court does not refer to Article 4(2) TEU in its decisions directly, neither does it use the notion of constitutional identity, ${ }^{30}$ to the concept of constitu-

Ibid., p. 66.

Ibid., p. 67.

6 KOCHENOV, D. and BÁRD, P.: Rule of Law Crisis in the New Member States of the EU. The Pitfalls of Overemphasing Enforcement. RECONNECT, Working Paper No. 1, 2018. [online] Available at: https://reconnect-europe.eu/wpcontent/uploads/2018/07/RECONNECT-KochenovBard-WP_27072018b.pdf . P. 12.

27 Moreover, the overall impression is completed by the rules according to which Hungarian constitutional judges are appointed.

28 HALMAI, G. Abuse of Constitutional Identity. The Hungarian Constitutional Court on Interpretation of Article E) (2) of the Fundamental Law. In Review of Central and East European Law. ISSN 0925-9880, 2018, vol. 43, no. 1, p. 23 - 42.

29 Article R(4) of the Fundamental Law of Hungary. 
tional identity corresponds in its case-law the concept of the so called material core of a constitution. ${ }^{31}$ It comprises of essential attributes of a democratic state governed by the rule of law the change of which is according to the Article 9(2) of the Czech Constitution impermissible. ${ }^{32}$ As regards more concrete content of these essential attributes, it is a result of the interpretation provided for by bodies applying the constitution in a concrete case. The guiding principle is undoubtedly the principle of inherent, inalienable, non-prescriptible, and nonrepealable fundamental rights and freedoms of individuals, equal in dignity and rights. A system based on the principles of democracy, the sovereignty of the people, and separation of powers, respecting the cited material concept of a law-based state, is built to protect them. According to the Czech Constitutional Court, these principles cannot be touched even by an amendment to the constitution implemented formally in harmony with law, because many of them are obviously of natural law origin, and thus the state does not provide them, but may and must - as a constitutional state - only guarantee and protect them. However, a detailed list of these principles cannot be found in any constitutional provision or in the Constitutional Court's case-law. As stated by Czech Constitutional Court itself, it has no ambition to make such a list in a case or a catalogue either. ${ }^{33}$

Kosař and Vyhnánek, besides constitutional identity in its form given by the Czech Constitutional Court, i.e. as an eternity clause, which they refer to as a legal constitutional identity in its thin version, differentiate also a so called legal constitutional identity in its thick version, comprised of additional principles of the substantive core that go beyond the eternity clause. These principles include for example a republican form of government or the nature of the Czech Republic as a unitary state that recognises territorial self-government. They also mention a so called popular constitutional identity which - in contrast to the legal constitutional identity which is based almost exclusively on the text of the Czech Constitution - goes beyond the constitutional text and is built around formative historical events in Czech as well as Czechoslovak history that are more understandable by the people than the abstract constitutional text. The popular constitutional identity comprises according to Kosař and Vyhnánek for example of the suffering of Czechs from the Germanisation and Catholisation of politics, as well as the suppression of the autonomy of Czech lands under the Austrian Empire, the creation of an independent Czechoslovakia in 1918, the Great Depression in the late 1920s and early 1930s, the Munich Treaty of 1938 and the subsequent annexation of Czech lands by the Third Reich in 1939, the 1946 free parliamentary elections and the subsequent communist coup d'état in 1948, the Prague Spring in 1968, the Velvet Revolution of 1989 and the dissolution of Czechoslovakia in $1993 .{ }^{34}$

This understanding of the constitutional identity is mentioned in relation to the decision of the Czech Constitutional Court Pl. ÚS 5/12 regarding Slovak pensions. ${ }^{35}$ Although the Czech Constitutional Court ruled the CJEU's judgment in the Landtová case to be ultra vires, it mentions also the constitutional identity of the Czech Republic „[...] which it draws from the com-

30 Exception could be its decision of 31 January 2012, Pl. ÚS 5/12, however, in the obiter dictum of that decision the Czech Constitutional Court only pointed out an alleged deficit of a fair trial before the CJEU in the case C-399/09 Landtová.

31 As regards the connection between the Czech constitutional identity and the material core of the Czech constitution, see KOSAŘ, D. and VYHNÁNEK, L: Constitutional Identity in the Czech Republic. In CALLIESS, CH. a VAN DER SHYFF, G.: Constitutional Identity in a Europe of Multilevel Constitutionalism. Cambridge: Cambridge University Press, 2020. ISBN 978-1-108-48043-7, p. 85 - 113.

32 See decision of the Czech Constitutional Court of 3 May 2006, Pl. ÚS 66/04, p. 82.

33 See decision of the Czech Constitutional Court of 26 November 2008, Pl. ÚS 19/08, p. 93.

34 KOSAŘ, D. and VYHNÁNEK, L: Constitutional Identity in the Czech Republic, op cit., p. 109.

35 Decision of the Czech Constitutional Court of 31 January 2012, Pl. ÚS 5/12. See in that regard also KOMÁREK, J.: Czech Constitutional Court Playing with Matches: The Czech Constitutional Court Declares a Judgment of the Court of Justice of the EU Ultra Vires; Judgment of 31 January 2012, Pl. ÚS 5/12, Slovak Pensions, XVII. In European Constitutional Law Review. ISSN 1744-5515, 2012, vol. 8, no. 2, p. 323 - 337. 
mon constitutional tradition with the Slovak Republic, that is from the over seventy years of the common state and its peaceful dissolution, i.e. from a completely idiosyncratic and historically created situation that has no parallel in Europe. "36

However, according to Kosař and Vyhnánek, the eternity clause does not pose a practical threat to the primacy of the EU law and the European integration because the Czech Constitutional Court's case-law can be considered quite euro-friendly. ${ }^{37}$ As the only exception may according to them be considered the decision of the Czech Constitutional Court in the Holubec case, that, however, can be - in their regard - hardly seen as a true reflection of the Court's attitude towards EU law. ${ }^{38}$

However, even if the above-mentioned decision was not considered as a reflection of the Court's attitude towards EU law, the Holubec decision as well as any other similar decision of whichever constitutional court of an EU Member State constitutes, in our view, a threat to the process of European integration. Such decisions may serve as an inspiration for some of the more resistant constitutional courts of EU Member States ${ }^{39}$ which instead of a proper reasoning as regards the potential theoretical and practical issues regarding the application of the concept of national identity in a concrete case only refer to the related case-law of other constitutional courts.

Moreover, within the context of the relationship between the constitutional courts of EU Member States and the Court of Justice of the European Union, a decision considered in the literature to be a result of the frustrated constitutional court because of the situation in a given state appears to be even more inappropriate. It also seems paradoxical that a constitutional court emphasizing the necessity for the legal certainty and continuity of a constitution and its interpretation adopted a decision that - as was already mentioned - reminds of an individual excess resulting from an undesirable situation for the national constitutional court.

\subsection{Slovak Republic}

Constitutional Court of the Slovak Republic has not mentioned the Slovak constitutional identity in relation to the EU law yet. However, it refers to the constitutional identity in its decision Pl. ÚS 21/2014 where it cites the literature in relation to the implicit material core of the Slovak constitution. ${ }^{40}$ According to the Slovak Constitutional Court, Slovak constitution is a value-oriented constitution with its implicit material core, which is necessary to be identified ad hoc. It, however, cannot be an ad hoc process in sense that ,, a provision of the Constitution is one time considered to be a part of the implicit core of the Constitution and later, in another case, is considered to be an element beyond the scope of the implicit core of the Constitution. " ${ }^{\text {"S1 }}$ Such practice would be incompatible with the requirement of the legal certainty and thus with the characteristics of a state based on the rule of law which are a necessary part of an implicit material core of the constitution. ,Searching for an implicit material core of the Constitution is an ad hoc searching in a sense that in every case regarding a constitutionality of a constitutional law, it is necessary to examine whether a challenged provision of the Constitution, which is allegedly breached by a constitutional law, is really a part of an implicit material core of the Constitution. " 42

Protection that is granted to the material core of the constitution serves as a protection of fundamental principles on which a modern European state is based on. According to the Slo-

\footnotetext{
36 Decision of the Czech Constitutional Court of 31 January 2012, Pl. ÚS 5/12, part VII.

37 KOSǍ̌, D. and VYHNÁNEK, L: Constitutional Identity in the Czech Republic, op cit., p. 101.

38 Ibid., p. 105.

39 As, for example, already mentioned decisions of the Polish and Hungarian constitutional courts.

40 Decision of the Slovak Constitutional Court of 30 January 2019, Pl. ÚS 21/2014, p. 55.

41 Ibid., p. 93

42 Ibid.
} 
vak Constitutional Court, the material core of the constitution is composed of principles of a democratic state based on the rule of law within the meaning of the Article 1(1) of the Slovak constitution. These principles - according to the Slovak Constitutional Court's case-law - are as follows: a principle of freedom, a principle of equality, a principle of human dignity, a principle of sovereignty of people - a principle of democracy respectively - , a principle of legality, supremacy of the constitution and laws, a principle of legitimacy, a principle of human rights and fundamental freedoms' protection, a principle of legal certainty including protection of legally acquired rights and legitimate expectations as well as prohibition of direct retroactivity, a principle of protection of people's trust in a legal order, a principle of justice known also as a principle of a state based on the rule of law, a principle of prohibition of arbitrariness - of prohibition of abuse of powers respectively, - a principle of proportionality, a principle of division of powers including a system of checks and balances and a principle of transparency or public control of the exercise of public authority. ${ }^{43}$ However, Slovak Constitutional Court emphasizes that such a list of principles of a democratic state based on the rule of law is not final. ${ }^{44}$

Such an understanding of a material core of a constitution is therefore very similar to the understanding of a constitutional core or a constitutional identity within the case-law of the Polish, Hungarian or Czech constitutional court. Its possible application is, however, still very difficult to predict. Slovak Constitutional Court is in its case-law quite euro-friendly, ${ }^{45}$ it is however necessary to point out that similar wording may be found in the case-law of other constitutional courts of the Visegrad group. Nevertheless, it is for now reasonable to assume that Slovak Constitutional Court would object to the violation of an implicit material core of the Slovak constitution, it would however do so only in exceptional cases. In times of growing tensions though, it still remains a question where - according to Slovak Constitutional Court - a borderline of such an exception would be.

\section{NATIONAL IDENTITY WITHIN THE CASE-LAW OF THE CJEU}

Attention to the particular case-law of the Court of Justice of the European Union was already paid elsewhere, ${ }^{46}$ we will, however, propose several conclusions in that regard.

Of a quite limited case-law of the CJEU regarding the national identity of EU Member States, its significant part pays attention to a linguistic or cultural aspect of this concept ${ }^{47}$ as well as to the elements which are specific for a given Member State. ${ }^{48}$ Court of Justice of the European Union considers the national identity to be a legitimate aim, nevertheless, in a case where a Member State refers to it, the CJEU applies a proportionality test.

However, in situations in which a Member State argues by the need of a higher fundamental rights protection, ${ }^{49}$ the CJEU refuses non-compliance with the obligations stemming from

\footnotetext{
43 See the decision of the Slovak Constitutional Court of 30 January 2019, Pl. ÚS 21/2014, p. 95 and the literature cited therein.

44 Ibid.

45 See, for example, decisions of the Slovak Constitutional Court of 26 January 2011, Pl. ÚS 3/09 or of 29 April 2015 , Pl. ÚS 10/2014.

46 MIHÁLIKOVÁ, V.: Národná identita členského štátu ako dôvod poskytnutia odlišnej miery ochrany základných práv v porovnaní s Chartou základných práv EÚ. In Acta Universitatis Carolinae Iuridica. ISSN 0323-0619, 2018, vol. LXIV no. 4, p. $39-52$.

47 See, for example, judgment of the Court of Justice of 2 June 1996, Commission v. Grand Duchy of Luxembourg, C473/93, EU:C:1996:263, judgment of the Court of Justice of 12 May 2011, Runevič-Vardyn, C-391/09, EU:C:2011:291 and judgment of the Court of Justice of 16 April 2013, Anton Las, C-202/11, EU:C:2013:239.

48 Judgment of the Court of Justice of 22 December 2010, Sayn-Wittgenstein, C-208/08, EU:C:2010:806 and judgment of the Court of Justice of 2 June 2016, Wolffersdorff, C-438/14, EU:C:2016:401.

49 Which, as results from the above mentioned case-law of the constitutional courts of the Visegrad group, is a part of their constitutional identity. This fact was referred to by Spanish government in its comments in the proceedings before the
} 
the EU law even when the Member State refers to its constitutional identity if it is necessary to maintain primacy, unity and effectiveness of EU law. ${ }^{50}$ It should not be overlooked in this regard that values which are mentioned by most of the constitutional courts in this context correspond to values on which the European Union is based and which are enshrined in the Article 2 TEU. ${ }^{51}$ It is therefore - in our view - understandable that the CJEU does not accept non-compliance with the EU law obligations by a Member State based on that Member State's understanding of values which are promoted and respected by the European Union itself.

\section{CONCLUSION}

As results from the above-mentioned, constitutional courts of the Visegrad group ${ }^{52}$ mostly use the concept of national identity understood as a material core of a constitution which cannot be affected not only by the European Union but also by the constituent power of the given state.

With the exception of the Slovak Constitutional Court, in relation to which it is only possible to speculate as regards its understanding of the national identity within the context of the Article 4(2) TEU, constitutional courts of the Visegrad group tend to be more resistant in relation to the Court of Justice of the European Union as well as the European Union in general. In the decision Pl. ÚS 5/12, the Czech Constitutional Court did not mention a violation of the constitutional identity of the Czech Republic, its approach however shows that it may come to this conclusion in the future. Moreover, it is impossible to overlook circumstances in Poland and Hungary when it comes to decisions of Polish and Hungarian constitutional courts.

We argue that the Article 4(2) TEU should not be an instrument used by constitutional courts in exceptional cases of conflict of the EU law and constitutional law of EU Member States and that it does not correspond to the concept of constitutional identity as an unchangeable core of a constitution or an eternity clause. National - or within the constitutional courts' point of view constitutional - identity would in this context be understood as a possibility of constitutional courts to rule that the EU law or an act of the European Union which only they would consider to be a part of the constitutional identity of a given state is inapplicable. The approach of constitutional courts of EU Member States is therefore in our view in contrast with the nature of the EU legal order. The concept of constitutional identity as they understand it does not correspond to the concept of national identity enshrined in the Article 4(2) TEU, in the sense of which the Member States should argue with the national identity only in proceedings before the CJEU and the EU legislator should take national identity of a Member State into consideration during the EU legislative process.

Even if we considered remarks regarding the constitutional identity in the case-law of the constitutional court isolatedly from the concept of national identity within the meaning of the Article 4(2) TEU, ${ }^{53}$ it cannot be overlooked that in the case-law of these courts, the idea of protection of constitutional identity is used - in particular in comparison with constitutional courts of Germany, Italy or Spain - in an unreasonable way. References to the constitutional

Court of Justice in the case C-399/11 Melloni as well as Italian or German constitutional court in their decisions regarding a constitutional identity.

50 See MIHÁLIKOVÁ, V: Národná identita členského štátu ako dôvod poskytnutia odlišnej miery ochrany základných práv v porovnaní s Chartou základných práv EÚ, op cit..

51 Article 2 TEU states: "The Union is founded on the values of respect for human dignity, freedom, democracy, equality, the rule of law and respect for human rights, including the rights of persons belonging to minorities. These values are common to the Member States in a society in which pluralism, non-discrimination, tolerance, justice, solidarity and equality between women and men prevail."

52 With the exception of the Constitutional Court of the Slovak Republic.

53 Since it is not our aim to doubt the significance of the constitutional identity as such. 
identity in the decision in which the constitutional court states that the act of the Union is an act ultra vires or in the decision adopted by the constitutional court which is referred to as political ${ }^{54}$ constitute an undesirable occurrence in the process of European integration and are in contrast with the ideas of the openness towards the EU law declared in other decisions of the mentioned constitutional courts. The example of this may be the Czech Constitutional Court which often uses as an inspiration the case-law of the German Constitutional Court and refers to it in its decisions, ${ }^{55}$ however, in its decision in the case Holubec, it maintained that the CJEU's judgment constitutes an act ultra vires without initiating proceedings before the CJEU and posing a preliminary question. It thus did not comply with the requirements of declaring an EU act to be an act ultra vires as drawn up by the German Constitutional Court in its case-law. ${ }^{56}$

It is not, we believe, very presumptuous to say that even the most passionate supporters of deepening of European integration do not doubt the significance of values which generally constitute a material core of constitution. However, in the interest of common and mutually advantageous functioning of the EU Member States and the EU itself, it would be without doubt desirable if some of the constitutional courts re-evaluated their application of the concept of national or constitutional identity. National identity within the context of Article 4(2) TEU should be in our view referred to by the EU Member States and in particular by their constitutional courts mainly in proceedings before the CJEU and with the use of references which would provide for reasons to apply this concept as a legitimate aim recognized by the European Union. Values inherent in the constitutional identities of EU Member States in the sense of a material core of a constitution or a so called eternity clause should - in compliance with the principle of sincere cooperation of Union and its Member States - be also an object of an open dialogue in the preliminary question proceedings, in particular taking into account the fact that it is also in the interest of the European Union to have these values promoted and respected - especially in times when their violation is pointed out in relation to Member States the constitutional courts of which do not hesitate to claim that the constitutional identity may be violated in a given case and find a reason for not fulfilling the obligations stemming from the EU law. It thus resembles a ,pot calling the kettle black“ situation. It, however, seems that in this case, the kettle stays clean.

\section{KEY WORDS}

national identity, constitutional identity, constitutional courts of the Visegrad group states, Court of Justice of the European Union

\section{KLÚČOVE SLOVÁ}

národná identita, ústavná identita, ústavné súdy štátov Vyšehradskej skupiny, Súdny dvor Európskej únie

54 See, for example, HALMAI, G.: The Hungarian Constitutional Court and Constitutional Identity. Verfassungsblog, 2017. [online] Available at: https://verfassungsblog.de/the-hungarian-constitutional-court-and-constitutional-identity/

55 Including the idea of the so called Europarechtsfreundlichkeit, i.e. the openness towards EU law.

56 It also fulfilled that requirement and submitted a preliminary question for example in the case Gauweiler. See the decision of the German Constitutional Court of 14 January 2014, 2 BvR2728/13. 


\section{BIBLIOGRAPHY}

\section{Monographs and articles}

1. BESSELINK, L.F.M.: National and Constitutional Identity before and after Lisbon. In Utrecht Law Review. ISSN 1871-515X, 2010, vol. 6, no. 3, http://doi.org/10.18352/ulr.139, p. $36-49$;

2. BLAGOJEVIĆ, A. Procedures Regarding National Identity Clause in the National Constitutional Court's and the CJEU's Case-law. In EU and Comparative Law Issues and Challenges. ISSN 2459-9425, 2017, no. 1, p. 210 - 237;

3. CLOOTS, E. National Identity, Constitutional Identity and Sovereignty in the EU. In Netherlands Journal of Legal Philosophy. 2016, vol. 45, no. 2, https://doi.org/10.5553/njlp/.000049, p. 83 - 84;

4. GUASTAFERRO, B.: Beyond the Exceptionalism of Constitutional Conflicts: The Ordinary Functions of the Identity Clause. Jean Monnet Working Paper 01/12. New York: NYU School of Law, 2012. ISSN 2161-0320;

5. HALMAI, G. Abuse of Constitutional Identity. The Hungarian Constitutional Court on Interpretation of Article E) (2) of the Fundamental Law. In Review of Central and East European Law. ISSN 0925-9880, 2018, vol. 43, no. 1, https://doi.org/10.1163/1573035204301002, p. 23 - 42;

6. HALMAI, G.: The Hungarian Constitutional Court and Constitutional Identity. Verfassungsblog, 2017. [online] Available at: https://verfassungsblog.de/the-hungarianconstitutional-court-and-constitutional-identity/

7. KOCHENOV, D. and BÁRD, P.: Rule of Law Crisis in the New Member States of the EU. The Pitfalls of Overemphasising Enforcement. RECONNECT, Working Paper No. 1, 2018. [online] Available at:

https://reconnect-europe.eu/wp-content/uploads/2018/07/RECONNECT-KochenovBardWP_27072018b.pdf;

8. KOMÁREK, J.: Czech Constitutional Court Playing with Matches: The Czech Constitutional Court Declares a Judgment of the Court of Justice of the EU Ultra Vires; Judgment of 31 January 2012, Pl. ÚS 5/12, Slovak Pensions, XVII. In European Constitutional Law Review. ISSN 1744-5515, 2012, vol. 8, no. 2, https://doi.org/10.1017/s1574019612000193, p. 323 - 337;

9. KOSAR̆, D. and VYHNÁNEK, L: Constitutional Identity in the Czech Republic. In CALLIESS, CH. a VAN DER SHYFF, G.: Constitutional Identity in a Europe of Multilevel Constitutionalism. Cambridge: Cambridge University Press, 2020. ISBN 978-1-10848043-7, https://doi.org/10.1017/9781108616256.005, p. 85 - 113;

10. MIHÁLIKOVÁ, V.: Národná identita členského štátu ako dôvod poskytnutia odlišnej miery ochrany základných práv v porovnaní s Chartou základných práv EÚ. In Acta Universitatis Carolinae Iuridica. ISSN 0323-0619, 2018, vol. LXIV no. 4, https://doi.org/10.14712/23366478.2018.32, p. 39-52.

11. ROSENFELD, M. Constitutional Identity. In ROSENFELD, M. and SAJÓ, A. The Oxford Handbook of Comparative Constitutional Law. Oxford: Oxford University Press, 2012. ISBN 978-0-19-957861-0, https://doi.org/10.1093/law/9780199578610.003.0037, p. $756-776$;

12. ŚLEDZIŃSKA-SIMON, A. and ZIÓŁKOWSKI, M.: Constitutional Identity of Poland: Is the Emperor Putting on the Old Clothes of Sovereignty? [online] Available at: https://ssrn.com/abstract=2997407; 
13. VON BOGDANDY, A. and SCHILL, S. Overcoming Absolute Primacy: Respect for National Identity under the Lisbon Treaty. In Common Market Law Review. ISSN 01650750, 2011, vol. 48, no. 5, p. $1417-1453$.

\section{Decisions of constitutional courts}

14. Decision of the Hungarian Constitutional Court of 30 November 2016, 22/2016 (XII. 5.) $\mathrm{AB}$;

15. Decision of the Polish Constitutional Court of 24 November 2010, K 32/09;

16. Decision of the Czech Constitutional Court of 3 May 2006, Pl. ÚS 66/04;

17. Decision of the Czech Constitutional Court of 26 November 2008, Pl. ÚS 19/08;

18. Decision of the Czech Constitutional Court of 31 January 2012, Pl. ÚS 5/12;

19. Decision of the Slovak Constitutional Court of 30 January 2019, Pl. ÚS 21/2014;

20. Decision of the Slovak Constitutional Court of 26 January 2011, Pl. ÚS 3/09;

21. Decision of the Slovak Constitutional Court of 29 April 2015, Pl. ÚS 10/2014;

22. Decision of the German Constitutional Court of 14 January 2014, 2 BvR2728/13;

\section{Judgments of the Court of Justice of the European Union}

23. Judgment of the Court of Justice of 17 December 1970, Internationale Handelsgesellschaft, 11-70, EU:C:1970:114;

24. Judgment of the Court of Justice of 2 June 1996, Commission v. Grand Duchy of Luxembourg, C-473/93, EU:C:1996:263;

25. Judgment of the Court of Justice of 12 May 2011, Runevič-Vardyn, C-391/09, EU:C:2011:291;

26. Judgment of the Court of Justice of 16 April 2013, Anton Las, C-202/11, EU:C:2013:239;

27. Judgment of the Court of Justice of 22 December 2010, Sayn-Wittgenstein, C-208/08, EU:C:2010:806;

28. Judgment of the Court of Justice of 2 June 2016, Wolffersdorff, C-438/14, EU:C:2016:401;

\section{Other sources}

29. Treaty on the European Union, OJ C 202, 7.6.2016, s. 13 - 388.

\section{CONTACT DETAILS OF THE AUTHOR JUDr. Valéria Miháliková}

$\mathrm{PhD}$ student

Pavol Jozef Šafárik University in Košice

Faculty of Law, Institute of International Law and European Law

Kováčska 26, 04075 Košice

Telefón: +421552344128

E-mail: valeria.mihalikova@student.upjs.sk 